\title{
PENGARUH BRAND IMAGE TERHADAP LOYALITAS WISATAWAN BERBELANJA DI TOKO OLEH-OLEH RAMA KRISNA TUBAN
}

\author{
Anggun Raswati ${ }^{1}$, I Wayan Suardana ${ }^{2}$, NGAS. Dewi ${ }^{3}$ \\ ${ }^{1}$ Email : raswatianggun@gmail.com \\ Program Studi Industri Perjalanan Wisata, Fakultas Pariwisata, Universitas Udayana \\ ${ }^{2}$ Email : suar.dana@yahoo.co.id \\ Program Studi Industri Perjalanan Wisata, Fakultas Pariwisata, Universitas Udayana \\ ${ }^{3}$ Email : susramid@gmail.com \\ Program Studi Industri Perjalanan Wisata, Fakultas Pariwisata, Universitas Udayana
}

\begin{abstract}
Increasing number of tourist will directly give impact to the tourism supporting industrial sector, one of them is Balinese souvenir industry. There are many Balinese souvenir shops in Bali, which make a competition among them becomes more intense, so every company will try to give a better impression for the tourists and try to make them satisfied and make them to visit again. One of the famous Balinese souvenir shop is a souvenir shop of Rama Krisna Tuban. This research aims to determin the influence of Brand Image on tourist loyalty. Respondents in this study amounted to 185 respondents, sample selection using the Purposive sampling method, the data in the study was analyzed using multiple regression analyses assisted by the SPSS statistical version 17.0 for Windows. The results of this research there are three factors that forms the Brand Image and it was found that there was a significant influence between the strength of brand associations on tourist loyalty, there was a significant influence between favorability of brand associations on tourist loyalty, and there was a significant influence between uniqueness of brand associations on tourist loyalty).
\end{abstract}

\begin{abstract}
Abstrak: Peningkatan jumlah kunjungan wisatawan ke Bali akan berimbas langsung terhadap sektor industri pendukung pariwisata, salah satunya industri oleh-oleh Khas Bali. Terdapat banyak toko oleh-oleh khas Bali sehingga membuat persaingan semakin ketat, untuk itu perusahaan akan terus memberikan kesan yang baik agar wisatawan puas dan berkunjung kembali, adapun salah satu toko oleh-oleh Khas Bali adalah toko oleh-oleh Rama Krisna Tuban. studi ini bertujuan untuk mengetahui pengaruh Brand Image terhadap loyalitas Wisatawan. Responden dalam studi ini berjumlah 185 responden, pemilihan sampel menggunakan metode purposive sampling, data dalam studi dianalisis menggunakan analisis regresi berganda yang di bantu oleh program statistikal SPSS version 17.0 for windows. Hasil studi ini adalah terdapat 3 faktor yang membentuk Brand Image dan diperoleh bahwa terdapat pengaruh signifikan antara kekuatan asosiasi merek dengan loyalitas wisatawan, terdapat pengaruh signifikan antara keuntungan asosiasi merek dengan loyalitas wisatawan, serta terdapat pengaruh signifikan keunikan asosiasi terhadap loyalitas wisatawan.
\end{abstract}

keywords: brand image, strength, favorability, and uniquesness of brand associantions, loyalty, tourist.

\section{PENDAHULUAN}

Jumlah kunjungan wisatawan ke Bali selalu meningkat dari tahun ke tahun. Peningkatan tersebut tentunya akan berimbas langsung terhadap sektor industri pendukung pariwisata, salah satunya industri oleh-oleh khas Bali. Toko Krisna merupakan toko oleholeh terbesar yang ada di Bali. Hal tersebut dikarenakan toko Krisna merupakan toko yang memiliki cabang toko oleh-oleh yang paling banyak di Bali. Ada berbagai macam yang dijual di Toko Krisna seperti barang fashion, souvenir, makanan hingga karya seni. Toko oleh-oleh Krisna ini didirikan oleh Gusti Ngurah Anom. Toko oleh-oleh Krisna ini telah memiliki 8 cabang yaitu Krisna Nusa Indah di Jl. Nusa Indah No.77 Denpasar- Bali, Krisna Nusa Kambangan di Jl. Nusa Kambangan 160A Denpasar-Bali, Krisna Sunset Road di Jl. Sunset Road No.88Abian Base Kuta-Bali, Rama Krisna di Jl. Tuban No.2x Bali, Krisna Oleh-Oleh Bali Singaraja di Jalan Seririt- 
Singaraja, Temukus, Banjar, Kabupaten Buleleng, Bali 81152, Krisna Oleh - Oleh Khas Bali Samasta lokasinya berada di Jalan Wanagiri, Jimbaran, Kuta Selatan, Kabupaten Badung, Bali 80361 , Krisna oleh-oleh Ubud Bali di di Peliatan, Kecamatan Ubud, Kabupaten Gianyar, Bali 80571.

Dalam waktu yang relatif singkat, Krisna Oleh-Oleh Khas Bali yang baru berdiri pada tahun 2007 cepat popular jika di bandingkan dengan toko oleh-oleh lainnya salah satunya seperti toko oleh-oleh Erlangga yaitu toko oleh-oleh pelopor di Bali yang sama persis dengan Krisna. Toko Erlangga telah berdiri seja tahun 1980-an. Selain Erlangga, terdapat pula toko oleh-oleh khas Bali yang sama dengan Krisna dan Erlangga yaitu, Agung Bali, Cening Bagus dan The Kranjang Bali. Jaringan kerjasama yang dibangun Gusti Ngurah Anom dengan praktisi pariwisata dan komponen pendukungnya seperti biro perjalanan, Himpunan Pramuwisata Indonesia (HPI) dan juga para pengemudi jasa angkutan wisata, taxi dan sebagainya dirasa sebagai terobosan jitu semakin mentenarkan nama Krisna Oleh-Oleh Khas Bali sebagai pusat belanja oleh-oleh Khas Bali dengan harga murah dan bermutu (Anggriawan, 2019). Sehingga membuat Toko Oleh-oleh Krisna.

Sejalan dengan perkembangan pariwisata di Bali, keberadaan toko oleh-oleh Krisnapun ikut memajukan kearifan lokal karena di toko tersebut menjual berbagai souvenir atau kerajinan tangan khas Bali, makanan khas Bali dan pakaian adat Bali. Berdasarkan hasil observasi sementara toko oleh-oleh Krisna menjadi toko oleh-oleh favorit bagi para pelanggannya, bahkan kemudian menjadi loyal terhadap toko oleholeh Krisna. Pelanggan yang dimaksud dalam hal ini yaitu wisatawan yang berkunjung ke Bali dan menjadi repeater guest dari toko oleh-oleh Krisna dengan membeli produk yang sama lalu kembali lagi di masa yang akan datang secara berulang-ulang.

Loyalitas pelanggan sangat dipengaruhi oleh brand image. Aaker dan Davis (dalam Palevi, 2018) berpendapat bahwa loyalitas terhadap suatu merek sangat dipengaruhi oleh beberapa banyak orang yang sudah loyal pada merek tersebut dikarenakan orang yang sudah loyal bisa mengajak dan menginformasikan kepada orang lain untuk membeli merek tersebut. Pelanggan yang percaya terhadap merek suatu perusahaan kemungkinan besar akan membeli kembali, bahkan menyebarluaskan kabar baik tentang perusahaan bersangkutan.

Citra terhadap merek berhubungan dengan sikap yang berupa keyakinan dan preferensi terhadap suatu merek. Konsumen yang memiliki citra yang positif terhadap suatu merek, akan lebih memungkinkan untuk melakukan pembelian (Setiadi dalam Palevi, 2018). Berdasarkan hasil studi sebelumnya mengenai Pegaruh Brand Iamge Terhadap Loyalitas Pelanggan di Toko Oleh-Oleh Malang Strudel yang dilakukan oleh Palevi dkk (2018) menyatakan bahwa kekuatan asosiasi merek (X1), Keunikan asosiasi merek (X2), dan keuntungan asosiasi merek (X3) yang membentuk brand image berpengaruh secara bersama-sama terhadap loyalitas pelanggan, dan studi sebelumnya dari Palevi dkk juga menyatakan bahwa sebesar 55\% loyalitas pelanggan dapat dijelaskan oleh kekuatan asosiasi merek, keunikan asosiasi merek, dan keuntungan asosiasi merek.

Berdasarkan hasil studi di lapangan dan berdasarkan hasil observasi sementara yang dilakukan brand image dari toko oleh-oleh Krisna adalah suatu toko yang menjual oleholeh khas Bali secara lengkap mulai dari baju, cindera mata, sampai makanan oleh-oleh khas Bali ada di Krisna (Wirawan, 2012). Sehingga dengan demikian wisatawan yang berkunjung ke Bali tidak perlu repot-repot untuk membeli oleh-oleh dengan mengunjungi beberapa tempat karena di Krisna sudah tersedia dengan lengkap, dari sanalah muncul pemikiran bahwa jika konsumen ingin memperoleh produk oleh-oleh khas Bali maka akan teringat Krisna oleh-oleh khas Bali.

Berdasarkan latar belakang diatas, brand image menjadi suatu komponen yang membentuk toko oleh-oleh Krisna dimata pelanggan. Sebagai salah satu toko oleh-oleh yang sedang berkembang dan sebagai salah satu toko oleh-oleh yang terbesar di Bali untuk itu perlu diketahui bagaimana pengaruh brand image terhadap loyalitas pelanggan di toko oleh-oleh Rama Krisna Tuban. Oleh karena itu perlu diadakananya studi ini untuk dapat menjelaskan bahwa loyalitas pelanggan di toko oleh-oleh Rama Krisna Tuban besar dipengaruhi oleh brand image seperti studi yang dilakukan oleh Palevi dkk atau sebaliknya.

Berdasarkan hasil studi sebelumnya mengungkapkan bahwa di dalam benak 
konsumen terdapat semua hal yang berhubungan dengan merek: pemikiran, perasaan, pengalaman, kesan, persepsi, keyakinan dan sikap-sikap suatu produk atau jasa. Asosiasi merek merupakan salah satu alat terpenting untuk mengukur mindset konsumen yaitu melihat dari kekuatan, kesukaan, dan keunikan atribut dan manfaat yang dirasakan konsumen dari suatu merek. Menurut Keller (dalam Niera, 2012). Dari penjelasan tersebut dapat disimpulkan bahwa asosiasi merek yang diungkapkan oleh Keller dapat tercermin makna dari apa yang konsumen rasakan terhadap citra suatu merek yang memuaskan kebutuhan konsumen sehingga dalam studi ini citra merek akan diukur dengan menggunakan tiga dimensi yang dikemukakan oleh Kevin Lane Keller. Dimensi-dimensi tersebut yaitu, strength of brand associations (kekuatan asosiasi merek), favorability of brand associations (keuntungan asosiasi merek), dan uniqueness of brand associations (Keunikan asosiasi merek).

Berdasarkan hal tersebut studi ini penting untuk diteliti karena agar terlihat sejauh mana Brand Image yang dicoba dibangun oleh toko oleh-oleh Rama Krisna Tuban untuk para wisatawannya agar wisatawan menjadi loyal. Sehingga memberikan manfaat apa saja yang harus diperbaiki oleh toko oleh-oleh Rama Krisna Tuban dalam hal membangun Brand Image yang positif agar wisatawan menjadi loyal.

\section{METODE}

Studi ini dilakukan di cabang ke empat dari toko oleh-oleh Krisna Bali yang diberi nama sebagai toko Rama Krisna yang berada di Jl. Tuban No.2x Bali. Penyebaran kuisioner dilakukan secara langsung ke lokasi dilakukannya studi kepada wisatawan domestik yang pernah berkunjung ke toko oleh-oleh Rama Krisna Tuban.

Teknik pengumpulan data dilakukan dengan observasi, dokumentasi, studi pustaka dan kuesioner. Teknik penentuan sampel dilakukan dengan purposive sampling, yakni metode pengambilan sampel dengan pertimbangan tertentu, yang artinya bahwa yang dapat dijadikan sampel adalah pelanggan dalam artian wisatawan domestik yang sudah pernah mengunjungi toko oleh-oleh Rama Krisna Tuban dan merasakan kualitas pelayanan di toko oleh-oleh Rama Krisna Tuban yang kemudian digunakan sebagai sumber data, dan pengambilan sampel dengan menggunakan teknik secara accidental yaitu teknik yang diambil berdasarakan kebetulan, yaitu responden yang secara kebetulan/incidental bertemu dengan peneliti dapat digunakan sebagai sampel, bila dipandang orang yang ditemui itu cocok sebagai sumber data. Adapun penentuan sampel dalam Studi ini dengan menggunakan model (J. Supranto dalam Palevi, 2018) yaitu mengalikan 5 sampai 10 dengan jumlah pertanyaan (indikator) dalam kuesioner. Jumlah indikator kuesioner dalam studi ini sebanyak 37, maka jumlah responden yang dijadikan sampel sebanyak 185 responden. Hasil tersebut diperoleh dari mengalikan 5 dengan 37 indikator dalam kuesioner. Teknik Analisis data dilakukan dengan uji validitas, uji reliabilitas, uji asumsi klasik dan analisis regresi linier berganda.

\section{HASIL DAN PEMBAHASAN Karakteristik Wisatawan}

Berdasarkan hasil analisis data dari kuisioner yang disebarkan secara menyuluruh maka diketahui dalam studi ini karakteristik responden. Karakteristik responden dalam studi ini meliputi jenis kelamin, usia, asal daerah, pekerjaan, perolehan informasi mengenai toko oleh-oleh Rama Krisna Tuban, frekuensi kunjungan ke toko oleh-oleh Rama Krisna Tuban, rekan yang Bersama-sama mengunjungi toko oleh-oleh Rama Krisna Tuban, pendorong wisatawan untuk berbelanja di toko oleh-oleh Rama Krisna Tuban, jenis produk yang biasa dibeli di toko oleh-oleh Rama Krisna Tuban, serta pengeluaran berbelanja di toko oleh-oleh Rama Krisna Tuban yang didapat dari hasil penyebaran kuesioner yang disebarkan kepada pelanggan toko oleh-oleh Rama Krisna Tuban. Karakteristik wisatawan berdasarkan jenis kelamin didominasi oleh perempuan sebesar 56,2 , berdasarkan usia didominasi oleh usia 17 - 27 tahun sebesar 49,7\%, berdasarkan asal daerah didominasi oleh Jawa Timur sebesar $22,2 \%$, berdasarkan pekerjaan didominasi oleh pegawai swasta sebesar $31,4 \%$, berdasarkan perolehan informasi mengenai toko oleh-oleh Rama Krisna Tuban didominasi oleh teman/keluarga sebesar $77,8 \%$, berdasarkan frekuensi kunjungan didominasi oleh 2-3 kali sebesar $74,1 \%$, berdasarkan rekan yang bersama-sama mengunjungi toko oleh-oleh Rama Krisna Tuban didominasi oleh 
teman/keluarga sebesar $95,7 \%$, berdasarkan hal yang mendorong wisatawan untuk berbelanja didominasi karena produk yang dijual lengkap dan kondisi toko nyaman sebesar $51,9 \%$, berdasarkan jenis produk yang biasa dibeli didominasi oleh pakaian yang bermotifkan seni Bali sebesar 36,2\%, dan berdasarkan besaran pengeluaran berbelanja didominasi sebesar Rp. 200.000 - Rp. 500.000 dengan persentase sebesar $58,9 \%$ rata-rata pengeluaran secara keseluruhan sebesar Rp. $120.000,00$.

\section{Analisis Pengujian Instrumen}

Uji validitas digunakan untuk mengetahui valid atau tidaknya suatu kuesioner. Suatu kuesioner dikatakan valid jika pertanyaan pada kuesioner mampu mengungkapkan suatu yang akan diukur oleh kuesioner tersebut Ghozali (2005). Dalam studi ini terdapat ke 23 indikator yang diteliti valid karena nilai koefisiennya melebihi 0,361 $(\mathrm{df}=\mathrm{n}-\mathrm{k}$, dengan Sig 5\%).

Selanjutnya pengujian reliabilitas yang digunakan untuk melakukan pengujian terhadap hasil dari jawaban kuesioner yang telah dilakukan, fungsi dari uji reliabilitas ini dilakukan untuk memperoleh hasil studi yang reliabel. Hasil uji reliabilitas terhadap 30 responden yang dijadikan sampel didapatkan hasil bahwa nilai Cronbach's Alpha adalah sebesar 0,892 , nilai ini dikatakan tersebut telah memenuhi syarat atau reliable, karena nilainya lebih dari 0,6.

\section{Uji Asumsi Klasik \\ Uji Normalitas}

Uji Normalitas menurut Sujarweni (2015) bertujuan untuk mengetahui distribusi data dalam variabel yang akan digunakan dalam studi. Uji statistik yang digunakan dalam studi ini adalah uji Kolmogrov-Smirnov dimana hasil analisisnya dibandingkan dengan nilai kritisnya. Diperoleh nilai Sig sebesar 0,173 yang dimana sesuai dengan pengambilan keputusan bahawa nilai sig harus lebih besar dari nilai 0,05 maka residual beretrubusi normal. Berdasarkan hal tersebut maka dapat disimpulkan bahwa Nilai sig 0.173 $>0.05$ maka studi ini beretribusi normal dan studi dapat dilanjutkan pada analisis selanjutnya.

\section{Uji Multikolinearitas}

Pengujian uji multikolinieritas dilakukan dengan melihat tolerance value atau dengan menggunakan Variance Inflation Factors (VIF) dengan menggunakan bantuan atau tolerance value di atas 0,10 . Nilai kekuatan asosiasi merek sebesar 2.280 dengan nilai Tolerance sebesar 0.439 , nilai VIF untuk keuntungan asosiasi merek sebesar 2.208 dengan nilai Tolerance sebesar 0.453 dan nilai VIF untuk keunikan asosiasi merek sebesar 1.652 dengan nilai Tolerance sebesar 0.605. Maka sesuai dengan pengambilan keputusan yang dimana Multikolinieritas tidak terjadi bila nilai VIF dibawah nilai 10 atau tolerance value di atas 0,10. (Hair et all, 1995) dalam Ismayanti (2015).

\section{Uji Heterokedestisitas}

Uji heteroskedastisitas bertujuan untuk menguji apakah dalam model regresi terjadi ketidaksamaan variance dari residual satu pengamatan yang lain. heterokedastisitas menunjukan bahwa variasi variabel tidak sama untuk semua pengamatan. Deteksi ada atau tidaknya heteroskedastisitas dapat dilihat dengan ada atau tidaknya pola tertentu pada grafik scatterplot. Jika ada pola tertentu maka mengindikasikan telah terjadi heteroskesdastisitas. Tetapi jika tidak ada pola yang jelas serta titik-titik menyebar di atas dan di bawah angka 0 pada sumbu Y, maka tidak terjadi heteroskedastisitas (Ghozali, dalam Halinda dkk, 2016). Pola dari scatterplot membentuk pola yang acak berada diatas dan di bawah titik 0. Oleh karena itu hasil diatas menjelaskan bahwa tidak terjadinya heterokedestisitas dalam studi ini.

\section{Analisis Regresi Linear Berganda}

Analisis regresi berganda adalah hubungan secara linear antara dua atau lebih variabel independen (X1, X2, dan X3) dengan variabel dependen (Y) Menurut Ghozali (2005). Analisis regresi berganda digunakan untuk menganalisis pengaruh variabel bebas yang terdiri dari Brand Image Terhadap Loyalitas Wisatawan di Toko Oleh - Oleh Rama Krisna Tuban. Persamaan model analisis regresi berganda dalam studi ini dapat dirumuskan:

$\mathrm{Y}=4.590+0,164(\mathrm{X} 1)-0,160(\mathrm{X} 2)+0,681+\mathrm{e}$ 
Berdasarkan hasil analisis data diperoleh persamaan yang dapat dijelaskan sebagai berikut:

1. Jika seluruh variabel bebas dinyatakan konstan pada angka nol (0), maka loyalitas pelanggan di toko oleh-oleh Rama Krisna Tuban sebesar 4.590.

2. Koefisien regresi kekuatan asosiasi merek (X1) adalah sebesar 0,164 menunjukkan bahwa variabel kekuatan asosiasi merek mempunyai hubungan positif terhadap loyalitas pelanggan di toko oleh-oleh Rama Krisna Tuban yang artinya semakin meningkat kekuatan asosiasi merek maka loyalitas pelanggan di toko oleh-oleh Rama Krisna Tuban akan meningkat sebesar 0,164.

3. Koefisien regresi keuntungan asosiasi merek (X2) adalah sebesar $-0,160$ menunjukkan bahwa keuntungan asosiasi merek mempunyai hubungan negatif terhadap loyalitas pelanggan di toko oleholeh Rama Krisna Tuban yang artinya semakin meningkat keuntungan asosiasi merek maka loyalitas pelanggan di toko oleh-oleh Rama Krisna Tuban tersebut akan menurun sebesar -0,160.

4. Koefisien regresi keunikan asosiasi merek (X3) adalah sebesar 0,681 menunjukkan bahwa variabel keunikan asosiasi merek mempunyai hubungan positif terhadap loyalitas pelanggan di toko oleh-oleh Rama Krisna Tuban yang artinya semakin meningkat keunikan asosiasi merek maka loyalitas pelanggan di toko oleh-oleh Rama Krisna Tuban akan meningkat sebesar 0,681 .

\section{Uji Signifikan Secara Parsial (Uji t)}

Uji statistik $t$ digunakan untuk mengetahui pengaruh masing-masing variabel independen secara parsial terhadap variabel dependen. Untuk mengetahui ada tidaknya pengaruh masing-masing variabel independen secara parsial terhadap variabel dependen dapat dilihat pada kriteria pengujian dengan tingkat signifikansi $5 \%$ atau sebesar 0,05 yaitu jika probability $t<0,05$ maka Ha diterima, sedangkan jika jika probability $t>0,05$ maka Ha ditolak (Ghozali, 2016). Diketahui bahwa variabel kekuatan asosiasi merek (X1) variabel keuntungan asosiasi merek (X2) dan variabel untuk variabel keunikan asosiasi merek berpengaruh secara parsial terhadap loyalitas pelanggan di toko oleh-oleh Rama Krisna
Tuban. Hasil pengujian menunjukan bahwa nilai Sig, untuk pengaruh $\mathrm{X} 1, \mathrm{X} 2$ dan $\mathrm{X} 3$ terhadap Y kurang dari 0.050. Maka Ho ditolak, yang berarti terdapat pengaruh kekuatan asosiasi merek (X1), keuntungan asosiasi merek (X2) dan keunikan asosiasi merek (X3) (independen) terhadap loyalitas pelanggan di toko oleh-oleh Rama Krisna Tuban (dependen). Berdasarkan hasil penelitian, maka dapat dijelaskan hasil studi ini akan memperkuat hipotesis sebagai berikut:

1. Kekuatan asosiasi merek (X1) berpengaruh positif dan signifikan terhadap loyalitas wisatawan (Y) dalam studi terdahulu yang dilakukan oleh Setyawan, Hapsari dan Prianto (2015) mendapatkan hasil bahwa secara parsial (individu) terdapat pengaruh yang positif dan signifikan Kekuatan Asosiasi Merek (X1) terhadap Loyalitas Konsumen. Selanjutnya studi terdahulu yang dilakukan oleh Wijayanto dan Iriani (2013) mendapatkan hasil bahwa kekuatan asosiasi merek (X1) secara simultan memiliki pengaruh yang signifikan terhadap loyalitas konsumen (Y). Keuntungan asosiasi merek berpengaruh negatif dan signifikan terhadap loyalitas pelanggan dalam studi terdahulu yang dilakukan oleh Palevi dkk (2018) mendapatkan hasil bahwa Keuntungan Asosiasi Merek (X2) berpengaruh secara parsial dan signifikan terhadap Loyalitas Konsumen. Selanjutnya studi terdahulu yang dilakukan oleh Wijayanto dan Iriani (2013) mendapatkan hasil bahwa kekuatan asosiasi merek (X1) secara parsial memiliki pengaruh yang signifikan terhadap loyalitas konsumen (Y).

2. Keunikan asosiasi merek berpengaruh positif signifikan terhadap loyalitas pelanggan dalam studi terdahulu yang dilakukan oleh Anggraini dan Ruzikna (2015) mendapatkan hasil bahwa Keunikan Asosiasi Merek (X3) memiliki indikator yang saling berkaitan dan berpengaruh posotif terhadap loyalitas pelanggan (Y). Selanjutnya studi terdahulu yang dilakukan oleh Yunaida (2017) Keunikan Asosiasi Merek (X3) berpengaruh secara signifikan terhadap loyalitas pelanggan $(\mathrm{Y})$. 


\section{Uji Signifikan Secara Simultan (Uji F)}

Uji $F$ pada dasarnya menunjukkan apakah semua variabel independen atau bebas yang dimasukkan dalam model mempunyai pengaruh secara bersama terhadap variabel dependen atau terikat. Probabilitas lebih kecil dari 0,05 maka hasilnya signifikan berarti terdapat pengaruh dari variabel independen secara bersama terhadap variabel dependen (Ghozali, 2005). Diketahui bahwa nilai $F_{\text {hitung }}$ yaitu 96.179 dengan signifikan $\mathrm{F}$ atau $p$-value sebesar 0,000 yang lebih kecil dari nilai $\alpha=$ $0,05(0,000<0,05)$. Sehingga dapat disimpulkan bahwa Kekuatan asosiasi merek (X1). Keuntungan asosiasi merek (X2) dan Keunikan asosiasi merek (X3) berpengaruh secara simultan terhadap loyalitas pelanggan di toko oleh-oleh Rama Krisna Tuban (Y). Variabel bebas yang digunakan pada studi ini dinyatakan layak memprediksi variabel terikat, sehingga pembuktian hipotesis dapat dilakukan.

\section{Analisis Koefisien Determinasi}

Koefisien determinasi bertujuan untuk mengukur seberapa jauh kemampuan model dapat menjelaskan variabel-variabel dependen. Pada pengujian hipotesis, hipotesis pertama koefisien determinasi dilihat dari besarnya nilai $\left(R^{2}\right)$ untuk mengetahui seberapa jauh variabel bebas yaitu Kekuatan Asosiasi Merek (X1), Keuntungan Asosiasi Merek (X2), dan Keunikan Asosiasi Merek (X3), serta pengaruhnya terhadap satu variabel dependen, yaitu Loyalitas Wisatawan di Toko Oleh-Oleh Rama Krisna Tuban (Y). Nilai $\left(R^{2}\right)$ mempunyai interval antara 0 dan 1 . Jika nilai $R^{2}$ bernilai besar (mendeteksi 1) berarti variabel bebas dapat memberikan hampir semua informasi yang dibutuhkan untuk memprediksi variabel dependen. Sedangkan jika $\left(R^{2}\right)$ bernilai kecil berarti kemampuan variabel bebas dalam menjelaskan variabel dependen sangat terbatas.

Besarnya nilai koefisien determinasi dari nilai $R^{2}$ Ini adalah 0,615 hal ini berarti $61,5 \%$ menunjukkan bahwa variabel dependen loyalitas wisatawan di toko oleholeh Rama Krisna Tuban (Y) dipengaruhi oleh variabel independen kekuatan asosiasi merek (X1), keuntungan asosiasi merek (X2) dan keunikan asosiasi merek (X3). Sedangkan sisanya $38,5 \%$ dijelaskan oleh variabel lain yang tidak terdapat dalam studi ini seperti pelayanan konsumen, citra perusahaan dan perilaku konsumen.

Kekuatan asosiasi merek (X1) memiliki nilai Sig. 0.000 yang dimana lebih kecil dari 0.05 dari nilai tersebut maka hipotesis pertama diterima karena terdapat pengaruh antara kekuatan asosiasi merek (X1) berpengaruh positif dan signifikan terhadap loyalitas wisatawan (Y). Untuk memperkuat studi ini maka akan dipaparkan studi terdahulu yakni studi dari Setyawan, Hapsari dan Prianto (2015) yang mendapatkan hasil bahwa Kekuatan Asosiasi Merek (X1) terdapat pengaruh yang positif dan signifikan terhadap Loyalitas Konsumen. Selanjutnya studi dari Wijayanto dan Iriani (2013) mendapatkan hasil bahwa kekuatan asosiasi merek (X1) secara simultan memiliki pengaruh yang signifikan terhadap loyalitas konsumen (Y).

Berdasarkan hasil penelitian disampaikan bahwa toko oleh-oleh Rama Krisna Tuban memiliki logo yang mudah diingat oleh responden yaitu nama dari toko oleh-oleh Rama Krisna Tuban sendiri yang diberi nama seperti nama salah satu dewa dari agama Hindu dan terdapat patung dewa Krisna yang lebih mencirikan toko oleh-oleh tersebut adalah toko oleh-oleh khas Bali yang mayoritas penduduknya beragama Hindu. Pendapat tersebut berkaitan dengan variabel kekuatan asosiasi merek (X1) seperti indikatornya yang menyebutkan bahwa Logo toko oleh-oleh Rama Krisna Tuban yang khas Bali dan Maskot toko oleh-oleh Rama Krisna Tuban yang mudah diingat oleh masyarakat, variabel ini menjelaskan mengenai attribute (fitur-fitur yang mendeskripsikan suatu produk atau jasa dari merek yang bersangkutan) khususnya mengenai product related attribute yang berkaitan dengan komposisi fisik dan tangible, maka atribut ini dapat dikenali secara langsung oleh panca indra, seperti bentuk, warna dan tampilan fisik dari suatu produk atau jasa. Berdasarkan pendapat responden tersebut bias terlihat bahwa toko oleh-oleh Rama Krisna Tuban telah dapat membuat wisatawan tersadar aan logo dan maskotnya yang mudah diingat. Berdasarkan hasil penelitian terlihat bahwa responden menikmati kenyamanan berbelanja di toko oleh-oleh Rama Krisna Tuban yang letaknya starategis yaitu dekat dengan bandar udara selain itu juga di dukung dengan jam buku toko oleh-oleh Rama Krisna Tuban yang buka selama 24 jam 
sehingga membuat wisatawan merasa lebih nyaman karena dapat berbelanja kapan saja. Pendapat dari responden tersebut berkaitan dengan brand benefit yaitu manfaat merek dari nilai personal yang melekat pada atribut produk atau jasa dan apa saja yang dapat diberikan produk atau jasa tersebut kepada konsumen. Seperti pendapat responden diatas bahwa toko oleh-oleh Rama Krisna Tuban buka selama 24 jam dan lokasinya dekat dengan airport pendapat tersebut merupakan salah satu dari contoh manfaat fungsional atau keuntungan intrinsic dari pemakai biasanya berkaitan dari atribut akan produk yang dapat memenuhi kebutuhan dan keinginan konsumen. Seperti toko oleh-oleh Rama Krisna Tuban yang buka selama 2 jam dan lokasinya dekat dengan airport memiliki manfaat utama sebab secara langsung mampu memuaskan kebutuhan konsumen dan sifatnya nyata. Sehingga dari kedua pendapat responden di atas dapat dikatakan bahwa kekuatan asosiasi merek di toko oleh-oleh Rama Krisna Tuban mempengaruhi wisatawan domestik dalam loyalitas pembelian oleh-oleh di toko oleh-oleh Rama Krisna Tuban.

Keuntungan asosiasi merek (X2) memiliki nilai Sig. 0.031 yang dimana lebih kecil dari 0.05 dari nilai tersebut maka hipotesis kedua diterima karena terdapat pengaruh antara keuntungan asosiasi merek (X2), berdasarkan perbandingan nilai tabel distribusi t, maka nilai t-hitung > t-tabel berpengaruh arah negatif dan signifikan terhadap loyalitas wisatawan $(\mathrm{Y})$ karena nilai t-hitung memiliki nilai negatif yaitu sebesar 2.116 (t-hitung) $\geq-1.973157$ (t-tabel). Berdasarkan hasil penyebaran kuesioner memperoleh hasil persentase rata-rata jawaban responden yang fluktuatif dimana wisatawan menjawab $0 \%$ untuk kategori sangat tidak setuju, $0,46 \%$ untuk kategori tidak setuju, $14,36 \%$ untuk kategori ragu-ragu, 49,65\% untuk kategori setuju, 35,52\% untuk kategori sangat setuju. Karena jawaban yang diberikan oleh responden dalam studi ini memberikan tanggapan yang fluktuatif membuat variasi dari jawaban responden yang tidak seimbang, sehingga terdapat hasil negatif dalam pengaruh keuntungan asosiasi merek (X2) terhadap loyalitas wisatawan (Y). Terjadinya hasil negatif dalam regresi dikarenakan perbedaan nilai variabel dependen dengan variabel independen, karena pada dasarnya regresi digunakan untuk mengukur variabel dependen
(Y) terhadap perubahan nilai variabel dependen, seperti yang diungkapkan oleh Dougherty (2002) yang dapat disimpulkan bahwa:

1. Konstanta negatif tidaklah menjadi persoalan dan bisa diabaikan selama model regresi yang diuji sudah memenuhi asumsi (misal normalitas untuk regresi sederhana) atau asumsi klasik lainnya untuk regresi ganda. Selain itu, selama nilai slope tidak NOL maka tidak perlu memperdulikan konstanta negatif ini.

2. Konstanta negatif umumnya terjadi jika ada rentang yang cukup jauh antara $X$ (variabel independen) dan Y (variabel respon. misal $\mathrm{X}$ memiliki rentang nilai 1 8, sedangkan Y memiliki rentang nilai 100 -200 .

Studi terdahulu yang dilakukan oleh Palevi dkk (2018) mendapatkan hasil bahwa Keuntungan Asosiasi Merek (X2) berpengaruh secara positif dan signifikan terhadap Loyalitas Konsumen. Selanjutnya studi terdahulu yang dilakukan oleh Susanty dan Adisaputra (2011) mendapatkan hasil bahwa keuntungan asosiasi merek berpengaruh secara positif dan signifikan terhadap loyalitas pelanggan. Hasil studi terdahulu yang dilakukan oleh Palevi (2018) dan Adisaputra (2011) bertolak belakang dengan studi yang dilakukan sekarang karena berpengaruh secara positif, sedangkan hasil studi ini mendapatkan hasil negatif. Berdasarkan hasil penelitian meyebutkan bahwa sebagian besar produk yang dijual di toko oleh-oleh Rama Krisna Tuban sama dengan toko oleh-oleh lainnya yang menyadari bahwa beberapa produk yang dijual di toko oleh-oleh Rama Krisna Tuban merupakan produk yang dikirim langsung dari produsennya langsung seperti pie susu yang jika wisatawan langsung membeli pie susu tersebut di toko produsennya langsung harganya akan jauh lebih murah akan tetapi karena toko oleh-oleh Rama Krisna Tuban menyediakan berbagai macam jenis produk yang dijual tidak hanya makanan saja melainkan souvenier juga masuk didalamnya sehingga membuat responden merasa lebih nyaman berbelanja di toko oleh-oleh Rama Krisna Tuban karena tidak perlu mencari produk oleh-oleh lainnya di tempat yang berbeda. Pendapat ini berkaitan dengan keuntungan asosiasi merek dimana konsumen percaya bahwa atribt dan manfaat yang diberikan oleh merek dapat memenuhi 
kebutuhan dan keinginan konsumen sehingga konsumen membentuk sikap positif terhadap merek. Seperti pendapat yang diutarakan oleh responden di atas bahwa responden tersebut menginginkan segala produk oleh-oleh didapatkan di dalam satu tempat yang nyaman oleh karena itu dapat dikatakan bahwa toko oleh-oleh Rama Krisna Tuban telah dapat menunjukan bahwa keuntungan asosiasi merek di toko oleh-oleh Rama Krisna Tuban telah dapat dirasakan karena wisatawan yang berkunjung telah mendapatkan keuntungan berdasarkan kebutuhan dan keinginan wisatawan. Berdasarkan hasil penelitian terlihat bahwa responden sesungguhnya mengetahui informasi ini berdasarkan respon positif dari kerabatnya yang telah berkunjung ke toko oleh-oleh Rama Krisna Tuban sebelumnya yang pada akhirnya membuat responden tersebut juga tertarik untuk berkunjung dan berbelanja di toko oleh-oleh Rama Krisna Tuban didukung pula dengan kelengkapan produk, kenyamanan toko dan lokasi toko yang strategis menambah keyakin responden untu selalu berbelanja oleh-oleh di toko oleh-oleh Rama Krisna Tuban.

Sehingga dari kedua pendapat tersebut dapat dikatakan bahwa kekuatan asosiasi merek di toko oleh-oleh Rama Krisna Tuban didapatkan hasil negatif karena banyak yang menilai bahwa produk yang dijual sesuangguhnya rata-rata sama jenis dan kualitasnya dengan toko oleh-oleh lainnya dan juga kurang gencarnya promosi berupa iklan yang dilakukan oleh pihak toko oleh-oleh Rama Krisna Tuban untuk menarik wisatawan berkunjung dan berbelanja karena kebanyakan wisatawan yang berbelanja ke toko oleh-oleh Rama Krisna Tuban karena mengetahui informasi dari kerabatnya yang pernah ke sana atau dari tour guide yang membawa wisatawannya untuk berbelanja oleh-oleh di toko oleh-oleh Rama Krisna Tuban. Akan tetapi karena kondisi toko yang nyaman, produk lengkap dan tertata rapi serta lokasi toko yang berada tidak jauh dari airport yang membuatnya lebih uanggul dibandingkan toko oleh-oleh lainnya sehingga dapat dikatakan bahwa kekuatan asosiasi merek di toko oleholeh Rama Krisna Tuban memang memiliki hasil yang negatif tetapi masih berpengaruh terhadap loyalitas pelanggan di toko oleh-oleh Rama Krisna tersebut.
Keunikan asosiasi merek (X1) memliki nilai Sig. 0.000 yang dimana lebih kecil dari 0.05 dari nilai tersebut maka hipotesis pertama diterima karena terdapat pengaruh antara keunikan asosiasi merek (X1) berpengaruh negatif dan signifikan terhadap loyalitas wisatawan (Y). Untuk memperkuat studi ini maka akan dipaparkan studi terdahulu yang dilakukan oleh Anggraini dan Ruzikna (2015) mendapatkan hasil bahwa Keunikan Asosiasi Merek (X3) memiliki indikator yang saling berkaitan dan berpengaruh positif terhadap loyalitas pelanggan (Y). Selanjutnya studi terdahulu yang dilakukan oleh Yunaida (2017) Keunikan Asosiasi Merek (X3) berpengaruh secara signifikan terhadap loyalitas pelanggan (Y). Berdasarkan hasil penelitian dapat dilihat bahwa responden merasa kondisi toko yang lebih nyaman dibandingkan toko oleh-oleh lainnya dan kelengapan produk yang membuat wisatawan tidak perlu repot untuk mencari di tempat lainnya. Pendapat tersebut beraitan dengan kemampuan toko oleh-oleh Rama Krisna Tuban yang dapat membuat kesan unik menunjukan perbedaan yang signifikan diantara merek-merek lain sebagai nilai saing dan membuat konsumen tertarik untuk memilik toko oleh-oleh Rama Krisna Tuban. Berdasarkan hasil penelitian terlihat bahwa responden merasakan perbedaan yang diberikan oleh toko oleh-oleh Rama Krisna Tuban mulai dari produk yang lengkap, pelayanan tambahan yang dapat memudahkan wisatawan untuk mengkemas barang belanjaannya, nama merek yang khas Bali dan mudah dingat, dan lokasi yang strategis yang membuat responden memilih untuk selalu berkunjung ke toko oleh-oleh Rama Krisna Tuban. Sehingga dari pendapat tersebut toko oleh-oleh Rama Krisna Tuban telah dapat menunjukan keunikannya dari toko oleh-oleh yang lain kepada wisatawan. Maka dapat dikatakan bahwa keunikan asosiasi merek di toko oleh-oleh Rama Krisna Tuban mempengaruhi loyalitas pelanggan di toko oleh-oleh Rama Krisna Tuban.

Berdasarkan hasil analisis diketahui bahwa nilai $F_{\text {hitung }}$ yaitu 96.179 dengan signifikan $\mathrm{F}$ atau $p$-value sebesar 0,000 yang lebih kecil dari nilai $\alpha=0,05(0,000<0,05)$. Sehingga dapat disimpulkan bahwa Kekuatan asosiasi merek (X1), Keuntungan asosiasi merek (X2), dan Keunikan asosiasi merek (X3) berpengaruh secara simultan terhadap loyalitas pelanggan di toko oleh-oleh Rama 
Krisna Tuban (Y). Variabel bebas yang digunakan pada studi ini dinyatakan layak memprediksi variabel terikat, sehingga pembuktian hipotesis dapat dilakukan. Untuk memperkuat studi ini maka dipaparkan studi terdahulu yang dilakukan oleh Neria (2012) mendapatkan hasil bahwa kekuatan asosiasi merek, keuntungan asosiasi merek, dan keunikan asosiasi merek secara barsama-sama terdapat hubungan yang kuat dan positif terhadap loyalitas pelanggan. Selanjutnya studi terdahulu yang dilakukan oleh Wijayanto dan Iriani (2013) mendapatkan hasil bahwa citra merek yang terdiri atas kekuatan asosiasi merek, keuntungan asosiasi merek, dan keunikan asosiasi merek secara simultan memiliki pengaruh yang signifikan terhadap loyalitas konsumen. Berdasarkan hasil penelitian dapat dikatakan bahwa responden merasa nyaman berbelanja di toko oleh-oleh Rama Krisna Tuban dan ingin kembali berbelanja oleh-oleh di toko oleh-oleh Rama Krisna Tuban karena kekuatan asosiasi merek yang telah tertanam di diri responden dengan dibuktikan dari pendapatnya yang menyebutkan bahwa toko oleh-oleh Rama Krisna Tuban dikenalnya sebagai toko oleholeh khas Bali yang memberikan manfaat untuknya akan memenuhi kebutuhan dan keingannya untuk berbelanja oleh-oleh tanpa terbatas waktu karena buka sela dua puluh empat jam dan lokasinya yang strategis dekat dengan airpot. Selain itu dari pendapat responden tersebut juga telah terbukti bahwa toko oleh-oleh Rama Krisna Tuban telah dapat memberikan keuntungan asosiasi merek yang baik kepada wisatawannya, dibuktikan dengan pendapat responden yang menyebutkan bahwa produk yang dijual di toko oleh-oleh Rama Krisna Tuban lengkap, unik dan khas Bali, serta toko oleh-oleh Rama Krisna Tuban juga telah dapat menunjukan keunikan asosiasi mereknya yang membuatnya berbeda dari toko oleh-oleh lainnya yang ada di Bali dengan dibuktikan oleh pendapat dari responden yang menyebutkan bahwa toko oleh-oleh Rama Krisna Tuban menyediakan produk berupa baju bergambar karikatur khas Bali yang diproduksinya sendiri yang tidak dapat ditemukan di toko oleh-oleh lainnya. Sehingga, dari pendapat tersebut dalam ditarik kesimpulan bahwa sudah terasanya kekuatan asosiasi merek, keuntungan asosiasi merek dan keunikan asosiasi merek yang membentuk brand image berpengaruh terhadap loyalitas wisatawan di toko oleh-oleh Rama Krisna Tuban.

\section{SIMPULAN DAN SARAN Simpulan}

1. Kekuatan asosiasi merek (X1) berpengaruh positif dan signifikan terhadap loyalitas wisatawan. Hal ini dapat dilihat dari hasil pengujian diperoleh nilai signifikan sebesar 0.000 , signifikansi uji $t$ lebih kecil dari 0.050 dan koefisien regresi mempunyai nilai positif (Sebesar, 0.164).

2. Keuntungan asosiasi merek (X2) berpengaruh negatif dan signifikan terhadap loyalitas wisatawan. Hal ini dapat dilihat dari hasil pengujian diperoleh nilai signifikansi sebesar 0.031, signifikansi uji $\mathrm{t}$ lebih kecil dari 0.050 dan koefisien regresi mempunyai nilai negatif (Sebesar, - 0.160).

3. Keunikan asosiasi merek (X3) berpengaruh positif dan signifikan terhadap loyalitas wisatawan. Hal ini dapat dilihat dari hasil pengujian diperoleh nilai signifikan sebesar 0.000 , signifikansi uji t lebih kecil dari 0.050 dan koefisien regresi mempunyai nilai positif (Sebesar, 0.681).

4. Kekuatan asosiasi merek (X1), Keuntungan asosiasi merek (X2), dan keunikan asosiasi merek (X3) berpengaruh secara positif dan signifikan secara bersama-sama atau simultan terhadap loyalitas pelanggan di toko oleh-oleh Rama Krisna Tuban.

\section{Saran}

1. Karyawan toko oleh-oleh Rama Krisna Tuban diberikan bimbingan yang lebih mengenai hospitality yang baik agar dapat memberikan pelayanan yang baik dan sesuai untuk wisatawan yang berkunjung ke toko oleh-oleh Rama Krisna Tuban seperti memberikan senyum setiap bertemu tamu, mengucapkan salam dan terima kasih, serta sigap untuk memberikan bantuan kepada wisatawan yang terlihat kebingungan atau kepada wisatawan yang membutuhkan bantuan.

2. Menyediakan lebih banyak lagi macam varian dari oleh-oleh yang disediakan agar wisatawan bisa lebih leluasa memilih produk yang sesuai dengan seleranya, atau bisa juga dengan mengkemas lebih unik produk yang sudah tersedia di toko oleh- 
oleh Rama Krisna Tuban agar terlihat lebih menarik.

3. Tersedianya lebih banyak jenis produk yang berbeda dengan toko oleh-oleh lainnya yang ada di Bali atau dengan lebih banyak memberikan informasi kepada konsumen untuk dapat menyadari bahwa baju atau kaos-kaso yang bertemakan karikatur khas Bali tersebut merupakan produk original dari Krisna Oleh-Oleh yang tidak akan di temukan di toko oleholeh lainnya.

4. Studi selanjutnya dapat mengembangkan studi ini dengan melakukan studi pada faktor-faktor lain yang dapat mempengaruhi loyalitas wisatawan. Besarnya faktor keunggulan asosiasi merek, keuntungan asosiasi merek dan keunikan asosiasi merek terhadap loyalitas pelanggan adalah sebesar $61,5 \%$ dan $38,5 \%$ merupakan faktor-faktor lain yang mempengaruhi loyalitas wisatawan selain faktor yang diteliti dalam studi ini. Studi selanjutnya dapat menganalisis faktorfaktor lain yang memberikan kontribusi terhadap loyalitas wisatawan pada toko oleh-oleh merek lainnya misalnya pengaruh kepuasan pelanggan terhadap loyalitas pelanggan di suatu toko oleholeh. 


\section{Kepustakaan}

Anggriani, Fitri. Dan Ruzika. 2015. Pengaruh Brand Image Terhadap Loyalitas Pelanggan Pada Koran Harian Riau. JOM FISIP. Vol. 3, No. 1, hlmn. 1-17.

Anggriawan, Yosia Nanda. 2019. "Analisis Tingkat Kepuasan Berbelanja Wisatawan Nusantara di Krisna OlehOleh Khas Bali" (skripsi). Denpasar: Universitas Udayana.

Dougherty, C. 2002. Introduction to econometrics. $2^{\text {nd }}$ ed. New York: Oxford.

Ghozali, Imam. 2005. Aplikasi Multivariate dengan Program SPSS. Semarang: Badan Penerbit Universitas Diponegoro.

_ . 2016. Aplikasi Analisis Multivariete Dengan Program IBM SPSS 23 (Edisi 8). Cetakan ke VIII. Semarang: Badan Penerbit Universitas Diponegoro.

Haslinda, Dan Jamaluddin. 2016. Pengaruh Perencanaan Anggaran dan Evaluasi Anggaran Terhadap Kinerja Organisasi Dengan Standar Biaya Sebagai Variabel Moderating Pada Pemerintah Daerah Kabupaten Wajo. Jurnal Ilmiah Akuntansi Peradaban. Vol. 2, No. 1.

Neria S, Melika . 2012. "Pengarauh Citra Merek Terhadap Loyalitas Konsumen Makapai Penerbangan Garuda Indonesia" (skripsi). Depok: Universitas Indonesia.

Palevi, Reza. 2018. Pengaruh Brand Image Terhadap Loyalitas Pelanggan di Toko
Oleh-Oleh Malang Strudel. Jurnal IPTA. Vol. 6, No. 1, hlmn. 70-76.

Setyawan, Deny. Hapsari, Astuti. Dan Prianto, Rendra. 2015. Pengaruh Manfaat Merek Kekuatan Asosiasi Merek dan Keunikan Merek Terhadap Loyalitas Konsumen Dalam Membeli Air Minum Kemasan Merek Aqua Di Kecamatan Semarang Barat. Jurnal Of Management . Vol. 1, No. 1, hlmn. 1-17.

Sujarweni, V. Wiratna. 2015. Statistik untuk Bisnis dan Ekonomi. Yogyakarta: Pustaka Baru Press.

Susanty, Aries. Adisaputra, Najid Bangun. 2011. Pengaruh Brand Image Speedy Telkom Terhadap Loyalitas Pelanggan Di Kecamatan Banyumanik Semarang. J@TI Undip. Vol. VI, No.3, hlmn. 147154.

Wijayanto, Indra. Dan Iriani, Sri Setyo. 2013. Pengaruh Citra Merek Terhadap Loyalitas Konsumen. Jurnal Ilmu Manajemen . Vol. 1, No. 3, hlmn. 910918.

Wirawan, Dodik, I Wayan Gede. 2012. Pengaruh Brand Image dan Customer Satisfaction Terhadap Word of Mouth di Krisna Oleh-Oleh Khas Bali. E jurnal Manajemen. Vol. 1, No. 1, hlmn. 77-89.

Yunaida, Erni. 2017. Pengaruh Brand Image (Citra Merek) Terhadap Loyalitas Konsumen Produk Oli Pelumas Evalube di Kota Langsa. Jurnal Manajemen dan Keuangan . Vol. 6, No. 2, hlmn. 798807. 